\title{
Management and treatment of liver injury in children
}

\author{
Serkan Arslan, M.D., ${ }^{1}$ Mahmut Güzel, M.D., ${ }^{2}$ Cüneyt Turan, M.D., ${ }^{2}$ \\ Selim Doğanay, M.D., ${ }^{3}$ Ahmet Burak Doğan, M.D., ${ }^{2}$ Ali Aslan, M.D. ${ }^{2}$
}

\begin{abstract}
1Department of Pediatric Surgery, Dr. Münif İslamoğlu Kastamonu State Hospital, Kastamonu;
${ }^{2}$ Department of Pediatric Surgery, Erciyes University Faculty of Medicine, Kayseri;

${ }^{3}$ Department of Radiology, Erciyes University Faculty of Medicine, Kayseri
\end{abstract}

\begin{abstract}
BACKGROUND: We aimed to assess the causes of trauma that result in liver injury and additional solid organ injuries, management types and results of management in children referred to our clinic for liver injuries.

METHODS: The records of 52 patients who were managed for liver injuries due to blunt abdominal trauma between January 20052010 were reviewed retrospectively.

RESULTS: The patients were I-I7 (8.3 \pm 5.4$)$ years old; $32(62 \%)$ were male and $20(38 \%)$ were female. Causes of injuries included pedestrian traffic accidents (19,37\%), falls from height (15,29\%), passenger traffic accidents $(8,15 \%)$, bicycle accidents $(8,15 \%)$, and objects falling on the body $(2,4 \%)$. Isolated liver injury was present in 32 patients $(62 \%)$, while 20 patients (38\%) had other organ injuries. Liver injuries were grade I in 6 patients (I2\%), grade II in I4 (28\%), grade III in 22 (43\%), grade IV in 9 (I7\%), and grade V in I (2\%). Forty-five patients (87\%) were managed conservatively in this series of liver injury, whereas seven patients (I3\%) who had unstable vital signs underwent surgery. The mortality rate, duration of stay in intensive care and hospital, and number of blood transfusions were higher in surgically managed patients, while hemoglobin level and blood pressure were significantly lower in surgically managed patients.
\end{abstract}

CONCLUSION: As a result, conservative management should be preferred in patients with liver injuries who are hemodynamically stable. Conservative management has some advantages, including shorter duration of stay in hospital, less need for blood transfusion and lower morbidity and mortality rates.

Key words: Children; hepatic; injury; liver; management; trauma.

\section{INTRODUCTION}

Liver injuries in children occur as a result of compression to the abdomen and thorax due to high-energy traumas like traffic accidents and falls from height. The liver is the second most commonly injured organ after blunt abdominal traumas. ${ }^{[1-3]}$ The most common cause of liver injury is trauma to the upper right abdomen or right hemithorax. Injuries occur mostly in the right liver lobe because of its localization and size. ${ }^{[4]}$

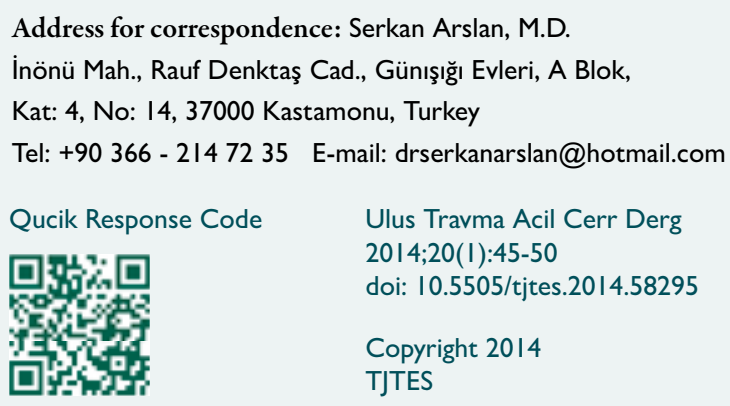

Ultrasonography (US), computed tomography (CT) and liver function tests (LFTs) are tools used for the diagnosis. Physical examination findings may not be sufficient for diagnosis even in serious injury. ${ }^{[5]}$ The liver takes blood from the systemic and portal circulation, so injury to the liver can cause serious blood loss. ${ }^{[1,3]}$

In hemodynamically stable patients, liver injuries are managed conservatively, but if there is hemodynamic instability, patients are managed surgically. ${ }^{[6]}$ Surgery is required if patients need blood transfusions of over $40 \mathrm{ml} / \mathrm{kg} /$ day or if there are findings indicating peritoneal irritation or hollow organ perforation. ${ }^{[1]}$ Segmental resections or repairs can be performed in surgery according to the type of injury. ${ }^{[4]}$ Complications like atelectasis, pneumonia, sepsis, intraabdominal abscess, and hemobilia and those due to blood transfusions have been observed after liver injuries. ${ }^{[1]}$

The aim of this study was to assess the types of trauma, management types in liver injuries and additional organ injuries, 
Table I. Other system and organ injuries

\begin{tabular}{lcc}
\hline & $\mathbf{n}$ & $\%$ \\
\hline Affected systems & & \\
Head & 6 & 12 \\
Thorax & 4 & 8 \\
Extremity & 4 & 8 \\
Multiple & 3 & 6 \\
Other intraabdominal injuries & & \\
Liver only & 32 & 62 \\
Kidney & 8 & 15 \\
Spleen & 8 & 15 \\
Gastrointestinal tract & 2 & 4 \\
Pancreas & 2 & 4 \\
\hline
\end{tabular}

and the success of management types in children referred to our clinic for liver injuries.

\section{MATERIALS AND METHODS}

The records of 52 patients who were managed for liver injuries due to blunt abdominal trauma between January 2005 and January 2010 were reviewed. Patients were grouped according to liver injury grades. Blood pressure, hemoglobin level, need for blood transfusion, and duration of stay in intensive care were compared between the groups (Table I). No records were excluded from the study.

General information, age, sex, duration of stay in hospital, causes of traumas, additional organ injuries, and treatment methods were evaluated. Hemodynamic status was determined with blood pressure at referral, hemoglobin levels, and need for blood transfusion.

All patients in the records were admitted to the intensive care unit, and heart rate, respiratory rate, blood pressure, and density and amount of urine were measured hourly, and hemoglobin level was monitored at the 6th and 24th hours. Routine biochemical laboratory parameters were checked in all patients.

Diagnoses of liver and additional organ injuries were made by anamnesis, physical examination, US, and/or CT examination. Liver injuries were graded using the classification of the American Association for the Surgery of Trauma (AAST) (Table 2). All US and CT images were interpreted by radiologists.

All hemodynamically stable liver injuries were managed conservatively. In the presence of suspected perforation on the physical examination and hemodynamic instability in spite of blood transfusions, an emergency laparotomy was performed.

Analyses were performed with the Statistical Package for the Social Sciences (SPSS) 19.0 statistical program. We used the Shapiro-Wilk test to determine the normality distribution of the variables. Independent comparisons among the groups were analyzed using a Kruskal-Wallis test. Median (minimummaximum) values were used to determine the numerical variables. Comparisons of categorical data were carried out using a Pearson's chi-square test. A p-value of less than 0.05 was considered statistically significant.

\section{RESULTS}

The patients were aged between I-I7 (8.3 \pm 5.4$)$ years; 32 (62\%) were male and 20 (38\%) were female. Causes of injuries were pedestrian traffic accidents (19,37\%), falls from height $(15,29 \%)$, passenger traffic accidents $(8,15 \%)$, bicycle accidents $(8,15 \%)$, and objects falling on the body $(2,4 \%)$ (Figure I).

Isolated liver injuries were observed in 32 (62\%) and additional injuries in 20 (38\%) patients. Among these, cranial injuries were commonly seen. The spleen and kidneys were the most affected intraabdominal organs. Additional injuries are summarized in Table I.

Table 2. Classification of the American Association for the Surgery of Trauma (AAST) ${ }^{[19]}$

\begin{tabular}{llcc}
\hline Grade & The size of liver laceration & n & $\%$ \\
\hline I & Small subcapsular haematoma or superficial laceration & 6 & 12 \\
2 & $\begin{array}{l}\text { Subcapsular haematoma covering } 10-50 \% \text { of surface area or a I-3 cm } \\
\text { laceration less than } 10 \mathrm{~cm} \text { in length }\end{array}$ & 14 & 28 \\
3 & $\begin{array}{l}\text { Large }(>50 \%) \text { ruptured subcapsular haematoma, an intraparenchymal } \\
\text { haematoma }>2 \mathrm{~cm} \text {, or a laceration }>3 \mathrm{~cm} \text { in depth }\end{array}$ & 22 & 43 \\
4 & $\begin{array}{l}\text { Ruptured intraparenchymal haematoma or lobar parenchymal } \\
\text { disruption involving } 25-50 \% \text { of the lobe }\end{array}$ & 9 & 17 \\
5 & Lobar parenchymal disruption $>50 \%$ or juxta-hepatic venous injury & 1 & 2 \\
6 & Hepatic avulsion & 0 & \\
\hline
\end{tabular}




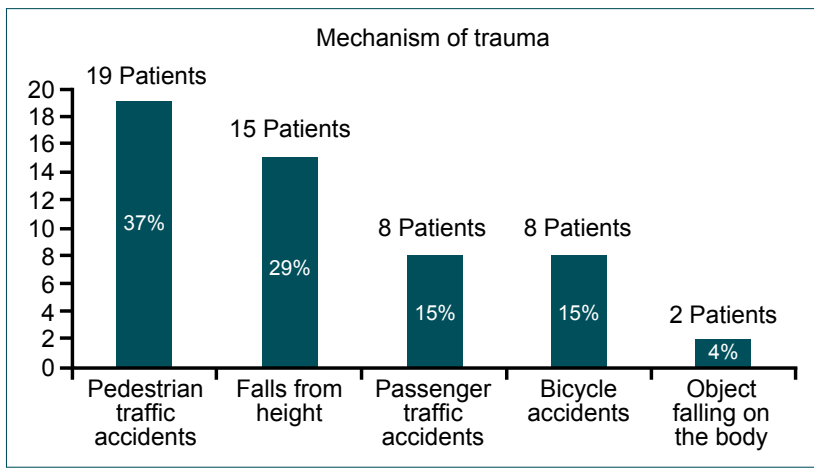

Figure 1. Causes of trauma.

On US examination, liver injuries were present in 42 (8I\%) and free fluid in the abdomen in 28 (54\%) patients. Liver injuries on US examination were graded by $\mathrm{CT}$ according to AAST classification. These injuries were classified as grade I in $6(12 \%)$, grade II in I4 (28\%), grade III in 22 (43\%), grade IV in 9 (I7\%), and grade $V$ in I (2\%) patient(s). There were no cases of grade VI liver injury in the present study. Grade I and II injuries were managed conservatively, while I patient (5\%) with grade III, 5 patients (50\%) with grade IV and I patient ( $100 \%$ ) with grade $V$ were managed surgically (Table 3 ).

Duration of stay in intensive care and hospital, hemoglobin levels, number of blood transfusions, and treatment methods according to injury grades on CT are summarized in Table 3. Increased number of blood transfusions, decreased rate of conservative management, increased rate of surgical management, and increased duration of stay in intensive care and hospital as the grade of injury increased were statistically significant $(p<0.05)$. However, decreased blood pressure and hemoglobin levels as grade of injury increased were not significant $(p>0.05)$.
Aspartate aminotransferase (AST) and alanine aminotransferase (ALT) levels were over $150 \mathrm{IU} / \mathrm{L}$ in 42 patients (8I\%), $40-150 \mathrm{IU} / \mathrm{L}$ in 8 patients (I5\%) and lower than $40 \mathrm{IU} / \mathrm{L}$ in 2 patients (4\%). ALT levels were $240 \mathrm{IU} / \mathrm{L}, 492 \mathrm{IU} / \mathrm{L}, 485 \mathrm{IU} / \mathrm{L}$, $437 \mathrm{IU} / \mathrm{L}$, and $420 \mathrm{IU} / \mathrm{L}$ in Grades I, II, III, IV, and V, respectively; AST levels were $336 \mathrm{IU} / \mathrm{L}, 627 \mathrm{IU} / \mathrm{L}, 600 \mathrm{IU} / \mathrm{L}, 50 \mathrm{I} \mathrm{IU} / \mathrm{L}$, and $400 \mathrm{IU} / \mathrm{L}$ in Grades I, II, III, IV, and V, respectively. Normal enzyme levels were observed in 2 patients with grade I injury. The relationship between enzyme levels and injury grade was not significant $(\mathrm{p}>0.05)$.

Forty-five patients (87\%) were managed conservatively in this series. All of these patients survived. Seven patients (I3\%) with unstable vital signs underwent surgery for liver injury. One of these patients had grade III injury, 5 had grade IV and I had grade $V$ injury. Segmentectomy was performed in 2 patients with grade IV injuries, and hepatic repair was carried out in 3 patients with grade IV injuries and in I patient with grade III injury. Liver resection was performed in the patient with grade $\mathrm{V}$ injury; this patient died perioperatively. Other patients managed surgically were discharged well. There were no long-term complications in the surgically managed patients.

In grade IV, the number of blood transfusions and duration of stay in intensive care and hospital were significantly lower in conservatively managed patients than in surgically managed patients, while hemoglobin level and blood pressure were significantly higher in conservatively managed patients than in surgically managed patients (Table 4).

In the conservatively managed group, 3 patients (7\%) had resorption fever, I ( $2 \%$ ) had a reaction to blood transfusion, I (2\%) developed atelectasis, I (2\%) had an intraabdominal abscess, and I (2\%) developed a lung infection postoperatively.

Table 3. The data according to the grades of liver injury

\begin{tabular}{|c|c|c|c|c|c|c|}
\hline & Grade I $(n=6)$ & Grade II $(n=\mid 4)$ & Grade III $(n=22)$ & Grade IV $(n=9)$ & Grade V $(n=I)$ & $p$ \\
\hline Systolic BP* & $\begin{array}{l}100 \mathrm{mmHg} \\
(97.5-120)\end{array}$ & $\begin{array}{l}110 \mathrm{mmHg} \\
(100-120)\end{array}$ & $\begin{array}{l}110 \mathrm{mmHg} \\
(100-120)\end{array}$ & $\begin{array}{l}110 \mathrm{mmHg} \\
(90-1 \mathrm{I} 2)\end{array}$ & $70 \mathrm{mmHg}$ & 0.923 \\
\hline Diastolic BP* & $\begin{array}{c}60 \mathrm{mmHg} \\
(60-80)\end{array}$ & $\begin{array}{c}70 \mathrm{mmHg} \\
(60-80)\end{array}$ & $\begin{array}{c}70 \mathrm{mmHg} \\
(60-70)\end{array}$ & $\begin{array}{c}70 \mathrm{mmHg} \\
(60-72)\end{array}$ & $40 \mathrm{mmHg}$ & 0.910 \\
\hline Hb level* & $\begin{array}{l}11.5 \mathrm{~g} / \mathrm{dL} \\
(9-12.5)\end{array}$ & $\begin{array}{c}12 \mathrm{~g} / \mathrm{dL} \\
(10.7-13)\end{array}$ & $\begin{array}{l}11.5 \mathrm{~g} / \mathrm{dL} \\
(10.7-12)\end{array}$ & $\begin{array}{l}11.5 \mathrm{~g} / \mathrm{dL} \\
(9-12)\end{array}$ & $7 \mathrm{~g} / \mathrm{dL}$ & 0.442 \\
\hline No. of transfusions & $2(33 \%)$ & $6(43 \%)$ & $16(73 \%)$ & $8(89 \%)$ & + & 0.007 \\
\hline $\begin{array}{l}\text { Duration of stayin } \\
\text { intensive care unit* }\end{array}$ & I day $(I-I)$ & I day $(\mid-2)$ & I day $(I-2)$ & 2 day $(1.7-3)$ & - & 0.007 \\
\hline $\begin{array}{l}\text { Duration of stayin } \\
\text { hospital }\end{array}$ & 4.5 days $(3-6)$ & 5 days $(3-6)$ & 5 days $(4-6)$ & 8 days $(5.5-1 \mathrm{I})$ & - & 0.030 \\
\hline No. of conservatively & $6(100 \%)$ & $14(100 \%)$ & 21 (95.4\%) & $4(44 \%)$ & - & $<0.001$ \\
\hline $\begin{array}{l}\text { No. of surgically } \\
\text { managed patients }\end{array}$ & 0 & 0 & I (4.5\%) & $5(56 \%)$ & $\begin{array}{c}+ \\
\text { (perop ex) }\end{array}$ & $<0.001$ \\
\hline
\end{tabular}

* Median (Min-Max) 
Table 4. The comparison of conservatively and surgically managed patients in grade IV

\begin{tabular}{|c|c|c|c|}
\hline Grade IV & $\begin{array}{c}\text { Conservatively managed } \\
\text { patients }(n=4)\end{array}$ & $\begin{array}{l}\text { Surgically managed } \\
\text { patients }(n=5)\end{array}$ & $p$ \\
\hline Systolic BP* & $100 \mathrm{mmHg}(100-130)$ & $90 \mathrm{mmHg}(85-95)$ & 0.008 \\
\hline Diastolic BP & $\begin{array}{c}70 \mathrm{mmHg} \\
(70-80)\end{array}$ & $\begin{array}{c}60 \mathrm{mmHg} \\
(60-65)\end{array}$ & 0.016 \\
\hline Hb level* & II g/dL (10-14) & $9 \mathrm{~g} / \mathrm{dL}(7-9)$ & 0.008 \\
\hline No. of transfusions & $2(75 \%)$ patients & $5(100 \%)$ patients & 0.444 \\
\hline $\begin{array}{l}\text { Duration of stayin } \\
\text { intensive care unit }\end{array}$ & I days $(I-I)$ & I days (2-3) & 0.008 \\
\hline $\begin{array}{l}\text { Duration of stayin } \\
\text { hospital }^{*}\end{array}$ & 5.5 days $(4-6)$ & II days (8-25) & 0.030 \\
\hline
\end{tabular}

\section{DISCUSSION}

The liver is the second most commonly injured intraabdominal organ after abdominal traumas. The rate of liver injury after blunt abdominal traumas is $2-3 \%$. Most liver injuries occur due to motor vehicle accidents and falls from heights. Penetrative injuries are rare in children. Surgical treatment is not necessary in $70-90 \%$ of patients. The aim of non-operative management of liver injuries in children is to reduce operative morbidity and mortality. ${ }^{[4]}$ The right diagnosis and treatment of liver injuries are very important in children because liver injury after blunt abdominal traumas is the most important cause of mortality. ${ }^{[7,8]}$

Leone et al. ${ }^{[9]}$ reported the cases of 27 patients with liver injury due to pedestrian traffic accidents ( 14 patients, $51 \%$ ), passenger traffic accidents ( 7 patients, $26 \%$ ), bicycle accidents (4 patients, I5\%), falls from height (I patient, $4 \%$ ), and assault (I patient, $4 \%$ ). In the present study, the rate of liver injuries due to pedestrian traffic accidents (19,37\%) was lower than that reported by Leone et al., whereas liver injuries due to falls from height $(15,29 \%)$ and bicycle accidents $(8,15 \%)$ were higher than in that study. Sociocultural differences could be the reason for this variation. In the study by Leone et al., I 3 patients (49\%) had grade I injury, 9 (33\%) had grade II injury, 3 (II\%) had grade III injury, and 2 (7\%) had grade IV injury. In the present study, more patients were classed in the higher grades compared to that study. It can be said that the patients admitted to our clinic had more severe traumas.

Landau et al. ${ }^{[10]}$ studied $31 \mathrm{I}$ patients, and reported that 136 patients (44\%) had isolated liver injury, while 175 patients (56\%) had additional injuries. These additional injuries were to the head in 147 patients (47\%), extremity fractures in 131 patients $(42 \%)$, and to the thorax in 66 patients $(21 \%)$. Other intraabdominal organ injuries in addition to liver injury were in the spleen (45 patients, 14\%), kidney (4 patients, 1\%) and pancreas (4 patients, I\%). In our study, 32 patients (62\%) had isolated liver injury and 20 patients (38\%) had other organ injuries in addition to liver injury. Other injuries included head $(6$ patients, $12 \%$ ), thorax (4 patients, $8 \%$ ), extremity (4 patients, $8 \%$ ), and multiple organ injuries (3 patients, $6 \%$ ). Liver injuries may occur frequently with the right kidney due to trauma to the right abdomen because of its dimensions and localization. Similarly, the spleen is the most injured organ with the left kidney due to trauma to the left abdomen. Injuries to the pancreas are uncommon because of its localization. ${ }^{[I]}$

Holmes et al. ${ }^{[1,12]}$ reported that the sensitivity of US for patients with abdominal trauma is $80 \%$. US determined liver lacerations in 42 patients $(81 \%)$ and free fluid in the abdomen in 28 patients $(54 \%)$ in the present study. These rates are similar to those in the literature. Simplicity, ease of use and no radiation are the main advantages of US. Its disadvantages are subjectiveness and low sensitivity with inexperienced users.

In several studies, AST and ALT levels over I50 IU/L indicated liver parenchymal damage in $43-61 \%$ of patients, but were unable to show the degree of parenchymal damage. ${ }^{[1,13]}$ However, in the present study, all patients had parenchymal damage, and 10 (19\%) of them had enzyme levels lower than $150 \mathrm{IU} / \mathrm{L}$. As in the literature, there was no relation between enzyme levels and injury grade in the present study. On the other hand, it has been reported that one can rule out liver parenchymal damage if enzyme levels are normal. ${ }^{[1,13]}$ As in the literature, in the present study, except for two patients with grade I injuries, increased AST and ALT levels were observed and all patients had liver parenchymal damage.

Hemoglobin level can decrease and there can be minimal leukocytosis in liver traumas. Karkiner et al. ${ }^{[14]}$ reported the cases of 75 patients whose blood transfusion rates were $13 \%$ for grade I, $20 \%$ for grade II, $30 \%$ for grade III, $50 \%$ for grade IV, and $100 \%$ for grade $V$ injuries. Ninety-seven percent of patients received conservative treatment and $3 \%$ of patients were managed surgically. In the present study, the transfu- 
sion rates were $33 \%, 43 \%, 73 \%$, and $100 \%$ for grades I, II, III, and grades IV-V, respectively. There were more blood transfusions in the present study than in other studies in the literature. Patients who received blood transfusion in the present study had hemoglobin levels of $10 \mathrm{~g} / \mathrm{dl}$ or lower at diagnosis or during the follow-up period. However, some clinics carry out blood transfusion when hemoglobin levels fall below 9 or $8 \mathrm{~g} / \mathrm{dl}$. This can explain the different figures in the literature regarding blood transfusion rates. Stabilization of patients hemodynamically is more difficult as the grade of injury increases. We found a statistically significant relation between the grade of injury and blood transfusion $(p=0.00)$. There was also a significant relation between the grade of injury and rate of surgery in the present study $(p=0.00)$. On the other hand, the relation between higher grade injury and lower hemoglobin level was not statistically significant $(p<0.05)$.

In the present study, durations of stay were I, I, I, and 2 days in intensive care and 4, 5, 5, 5, and 8 days in hospital for grades I, II, III, and IV, respectively. There was a statistically significant relationship between grade of injuries and duration of stay in intensive care and in hospital $(p<0.05)$. Nellensteijn et al. ${ }^{[15]}$ reported that durations of stay were $0,0,0$, and I days in intensive care and 2, 3, 4, and 5 days in hospital for grades I, II, III and IV, respectively. In that study, there was also a significant relation between the grade of injury and duration of stay in intensive care and in hospital. However, durations of stay in intensive care and in hospital were longer in the present study than in that of Nellenstein et al. This may have been because more severe traumas, and as a result, more severe injuries were observed in the present study.

Conservative management is successful in $90 \%$ of liver injuries. After discharge, absolute bed rest for 7-10 days and limited physical activity for 4-6 weeks are recommended. ${ }^{[16,17]}$ Forty-five of 52 patients (87\%) were managed conservatively in the present study. Of these patients, $20(100 \%)$ with grade I and II injuries, 2 I (95\%) with grade III injuries and four (40\%) with grade IV injuries were managed conservatively. There was transfusion reaction in three patients $(7 \%)$ in the followup period.

Surgical management of liver injury has a higher mortality rate than conservative management because liver resection increases the risk of perioperative and postoperative mortality. ${ }^{\left[{ }^{[18]}\right.}$ Kepertis et al. ${ }^{\left[{ }^{[9]}\right.}$ managed 9 of 34 patients $(26 \%)$ surgically. Two of these patients had grade IV injuries, one had grade $\mathrm{V}$ and one had grade $\mathrm{Vl}$; two of the other five patients underwent surgery for splenic laceration, two for head injury, one for diaphragmatic rupture, and one for extremity fracture. There was I (I I\%) mortality in the surgically managed patients and no incidence of mortality in the conservatively managed patients in the study of Kepertis et al. ${ }^{[19]}$ Similarly, in the present study, the mortality rate was high in the surgically managed patients, as one out of seven patients (14\%) died. In the present study, duration of stay in intensive care and in hospital and number of blood transfusions were higher in surgically managed patients, while hemoglobin level and blood pressure were significantly lower in surgically managed patients.

In $25 \%$ of all liver traumas, complications such as atelectasis and pneumonia can be seen. In the present study, of the 45 patients who were managed conservatively, three patients (6.6\%) had atelectasis and one patient (2.2\%) developed pneumonia. Our complication rate was lower than that in the literature due to the conservative approach adopted in this study. On the other hand, there were no complications in the six surviving patients managed surgically. However, the lower complication rate observed in surgically managed patients in the present study was probably due to the low patient numbers. The incidence of intrahepatic or subhepatic abscess is $0.5-3 \%{ }^{\left[{ }^{[]}\right.}$As in the literature, one patient who was managed conservatively $(2.2 \%)$ had subhepatic abscess in the present study.

In conclusion, conservative management has some advantages, including shorter duration of stay in hospital, less need for blood transfusion and lower morbidity and mortality rates. Therefore, conservative management should be preferred in liver injuries in patients who are hemodynamically stable.

\section{Conflict of interest: None declared.}

\section{REFERENCES}

1. Basaklar AC, Türkyılmaz Z. Abdominal and thoracic trauma. In: Başaklar AC, editor. Bebek ve çocukların cerrahi ve ürolojik hastalıkları. Ankara: Palme Yayincilik; 2006. p. 1015-50.

2. Bluett MK, Woltering E, Adkins RB. Management of penetrating hepatic injury. A review of 102 consecutive patients. Am Surg 1984;50:132-42.

3. Bond SJ, Eichelberger MR, Gotschall CS, Sivit CJ, Randolph JG. Nonoperative management of blunt hepatic and splenic injury in children. Ann Surg 1996;223:286-9. CrossRef

4. Gross M, Lynch F, Canty T Sr, Peterson B, Spear R. Management of pediatric liver injuries: a 13-year experience at a pediatric trauma center. $J$ Pediatr Surg 1999;34:811-7. CrossRef

5. Feigin E, Aharonson-Daniel L, Savitsky B, Steinberg R, Kravarusic D, Stein $\mathrm{M}$, et al. Conservative approach to the treatment of injured liver and spleen in children: association with reduced mortality. Pediatr Surg Int 2009;25:583-6. CrossRef

6. Coburn MC, Pfeifer J, DeLuca FG. Nonoperative management of splenic and hepatic trauma in the multiply injured pediatric and adolescent patient. Arch Surg 1995;130:332-8. CrossRef

7. Keller MS. Blunt injury to solid abdominal organs. Semin Pediatr Surg 2004;13(2):106-11. CrossRef

8. Eppich WJ, Zonfrillo MR. Emergency department evaluation and management of blunt abdominal trauma in children. Curr Opin Pediatr 2007;19:265-9. CrossRef

9. Leone RJ Jr, Hammond JS. Nonoperative management of pediatric blunt hepatic trauma. Am Surg 2001;67:138-42.

10. Landau A, van As AB, Numanoglu A, Millar AJ, Rode H. Liver injuries in children: the role of selective non-operative management. Injury 2006;37:66-71. CrossRef 
11. Sivit CJ. Imaging children with abdominal trauma. AJR Am J Roentgenol 2009;192:1179-89. CrossRef

12. Holmes JF, Gladman A, Chang CH. Performance of abdominal ultrasonography in pediatric blunt trauma patients: a meta-analysis. J Pediatr Surg 2007;42:1588-94. CrossRef

13. Taylor GA, Sivit CJ. Posttraumatic peritoneal fluid: is it a reliable indicator of intraabdominal injury in children? J Pediatr Surg 1995;30:1644-8.

14. Karkiner A, Temir G, Utku M, Uçan B, Hoşgör M, Karaca I. The efficacy of non-operative management in childhood blunt hepatic trauma. Ulus Travma Acil Cerrahi Derg 2005;11:128-33.

15. Nellensteijn D, Porte RJ, van Zuuren W, ten Duis HJ, Hulscher JB. Pae- diatric blunt liver trauma in a Dutch level 1 trauma center. Eur J Pediatr Surg 2009;19:358-61. CrossRef

16. Oldham KT, Guice KS, Ryckman F, Kaufman RA, Martin LW, Noseworthy J. Blunt liver injury in childhood: evolution of therapy and current perspective. Surgery 1986;100:542-9.

17. Celebi F, Balik AA, Polat KY, Yildirgan MI, Böyük A, Oren D. Hepatic injuries. Surgical treatment experience. Ulus Travma Derg 2001;7:185-8.

18. Pachter HL, Hofstetter SR. The current status of nonoperative management of adult blunt hepatic injuries. Am J Surg 1995;169:442-54. CrossRef

19. Kepertis C, Zavitsanakis A, Filippopoulos A, Kallergis K. Liver trauma in children: Our experience. J Indian Assoc Pediatr Surg 2008;13:61-3.

\section{KLINIK ÇALIŞMA - ÖZET}

\section{Çocuklarda karaciğer yaralanmasında yönetim ve tedavi}

\section{Dr. Serkan Arslan,, ${ }^{1}$ Dr. Mahmut Güzel, ${ }^{2}$ Dr. Cüneyt Turan, ${ }^{2}$ Dr. Selim Doğanay, ${ }^{3}$ Dr. Ahmet Burak Doğan, ${ }^{2}$ Dr. Ali Aslan}

${ }^{1}$ Dr. Münif İslamoğlu Kastamonu Devlet Hastanesi, Çocuk Cerrahisi Kliniği, Kastamonu;

${ }^{2}$ Erciyes Üniversitesi Tıp Fakültesi, Çocuk Cerrahisi Anabilim Dalı, Kayseri;

${ }^{3}$ Erciyes Üniversitesi Tıp Fakültesi, Radyoloji Anabilim Dalı, Kayseri

AMAÇ: Karaciğer travması nedeniyle son 7 yılda kliniğimize başvuran çocuklarda travma tiplerini, eşlik eden solid organ yaralanmalarını, tedavilerini ve tedavi sonuçlarını değerlendirmektir.

GEREÇ VE YÖNTEM: Kliniğimizde Ocak 2005-Ocak 2012 arasında künt karın travmalarına bağlı karaciğer yaralanması nedeniyle tedavi edilen 52 hasta retrospektif olarak değerlendirildi.

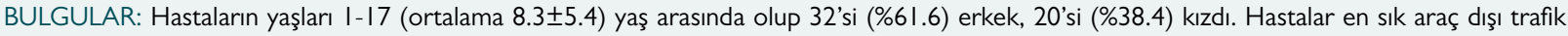
kazası (19,\%37), yüksekten düşme (15, \%29), araç içi trafik kazası $(8, \% 15)$, bisiklet kazaları $(8, \% 15)$ ve üzerine cisim düşme $(2, \% 4)$ nedeniyle başvurdu. Hastaların 32'sinde (\%6।.5) izole karaciğer, 20'sinde (\%38.5) eşlik eden diğer organ yaralanmaları vardı. Hastaların 6'sında kafa (\%। I.5), 4'ünde (\%7.6) toraks, 4'ünde (\% 7.6) ekstremite, 3'ünde (\%5.7) çoklu yaralanma vardı. Karıniçi organlardan 8'inde böbrek (\%।5), 8'inde (\%।5) dalak, 2'sinde (\%4) GiS, 2'sinde (\%4) pankreas yaralanması vardı. Altı hasta (\% II.5) Evre I, I4 hasta (\%27) Evre II, 22 hasta (\%42.5) Evre III, 9 hasta (\%।7) Evre IV, I hasta (\%2) Evre V idi. Evre I ve II olan tüm hastalar konservatif tedavi yapilırken, cerrahi tedavi yapılan I hasta (\%4.5) evre III, 5 hasta (\%50) evre IV, I hasta (\%। 00) ise Evre V idi. Bu çalş̧mada 52 hastanın 45’i (\% 86.5) konservatif takip edilirken, vital bulguları stabil olmayan 6 hasta ameliyat edildi. Bir hasta ameliyat sırasında hayatını kaybetti (\%।.9).

TARTIŞMA: Sonuç olarak, karaciğer travmalarında hemodinamik olarak stabil seyreden hastalarda konservatif tedavi tercih edilmelidir. Çocuklarda karaciğer travmalarının çoğu konservatif tedavi edilebilmektedir. Konservatif tedavi daha kısa hastanede kalış süresi, daha az transfüzyon ihtiyacı, morbiditenin ve mortalitenin daha düşük olması gibi avantajlara sahiptir.

Anahtar sözcükler: Çocuk, hepatik; karaciğer; tedavi yönetimi; travma; yaralanma.

Ulus Travma Acil Cerr Derg 20।4;20(I):45-50 doi: 10.5505/tjtes.20।4.58295 